\title{
Dealing with Insulation in a House
}

\author{
Naje Mohamed Abdulla ${ }^{1}$, Ervin Lumnitzer ${ }^{2 *}$ \\ 1,2 Technical university of Košice, Faculty of Mechanical Engineering, Department of Environmental Studies and Process Control
}

\section{BIOGRAPHICAL NOTES}

Ervin Lumnitzer, prof. Ing. PhD. He is graduated at Technical University of Košice in the field of "Robototechniques" in 1985. In 1995 he defended his dissertation thesis in field of "Mechanical Technologies" and in 2002 habilitated in the field of "Automation and Control". Nowadays he works as a university teacher. He is the head of the Environmental Engineering Department, authorized person for noise measurements in living and working environment, referee of bachelor stud ies in field of Environmental Management, chairman and also member of board of state examiners. Lately he is focused on the field of noise measurements and assessment, protection against industrial noise, noise mapping, noise visualization, assessment of the working environment quality.

\section{KEY WORDS}

Thermal insulation, payback equation, ceiling, walls.

\section{ABSTRACT}

This paper focuses on the optimal ways of insulation of a house. It also discusses places in a house that should be or should not be insulated in order to gain maximum energy effiency and to avoid problems with humidity, moisture accumulation and the like that can be caused if the insulation is installed in a wrong or improper way. It also mentions payback equation that could help assess if the investment in the insulation managed to save energy and money for the resident or not and to what extent it managed to do so.

\section{Introduction}

Every year thousands of euros are wasted on ineffective handling with heating. Thermal insulation could help save this money while keeping thermal comfort of the residents of the house. The right type of insulation can prevent the house from problems with moisture in the house and maintain the comfort temperature in the building. [1].

\section{Proper Insulation of Places in Houses in Order to Gain the Highest Possible Energy Efficiency}

In order to reach optimal energy efficiency, houses, buildings and edifices should be properly insulated. Loose-fill or batt insulation is usually used to insulate attic area. Loose-fill insulation is usually less expensive to be installed and it provides better coverage at the properly-used procedure of installation. Any holes, leaks, knee walls, vertical walls in the house must be sealed before insulation as well. If the pipes in a house are in unconditioned space, it is necessary to seal and insulate them in order to avoid heat losses $[2,3]$.

To provide uniformly distributed temperature in the house, proper insulation of the cathedral ceilings will be needed. This insulation will allow ceiling temperatures to get closer to the actual temperatures in the rooms. Cathedral ceilings must provide 
space between the roof deck and home's ceiling for adequate insulation and ventilation. Foil-faced batt insulation is often used in cathedral ceilings because it provides the permeability rating often required for use in ceilings without attics $[2,3]$.

Rigid foam insulation should be added under the rafters, which adds R-value and eliminates thermal bridging through wood rafters. However, rigid foam insulation must be covered with a fire-rated material when used on the interior of a building. In an existing home, using loose-fill or sprayed foam insulation, which can be added to exterior walls without much disturbance to finished areas of house, must be considered [2].

In the design phase of new house, structural insulated panels, insulating concrete forms, and insulated concrete blocks should be considered. These materials have insulation built in, and houses built using these products often have superior insulating qualities and minimal thermal bridging [2].

When insulating floors above unheated garages, first all possible sources of air leakage should be sealed. Also an air barrier to prevent cold air in the garage from "short circuiting" the insulation underneath the subfloor should be installed. In addition to reducing heating costs, a properly insulated foundation will keep below-grade rooms more comfortable and prevent moisture problems, insect infestation. A properly insulated basement can save money on heating and provide a dry, comfortable living space. In most cases, a basement with insulation installed on its exterior walls should be considered a conditioned space. Even in a house with an unconditioned basement, the basement is more connected to other living spaces than to the outside, which makes basement wall insulation preferable to ceiling insulation $[2,3]$.

In new construction, adding insulation on the exterior of the basement walls will minimize thermal bridging and reduce heat loss through the foundation, will protect the damp-proof coating from damage during backfilling, provide some protection against moisture intrusion, protect the foundation from the effects of the freeze-thaw cycle in extreme climates, reduce the potential for condensation on surfaces in the basement, conserve room area, relative to installing insulation on the interior. In an existing home, adding insulation to the exterior of the basement walls is impractical $[2,3]$.

\section{Payback of the Insulation Installation}

Payback of the insulation installation is considered as the time period required for the insulation to save fuel used for heating at present prices to pay for its installation. A simple payback is the initial investment divided by annual savings. The payback equation is suitable only for uniform sections of the assessed house. Parts of house with different R-values must be calculated separately. When calculating payback for wall insulation, the areas of windows and doors must be subtracted. The cost of the energy source is also a key factor in determining payback. Energy prices vary from season to season. The weather from year to year also varies, so energy costs of the house will vary from year to year too. The following equation is used to calculate payback of the insulation installation in years:

Years to payback $=$

$$
\frac{(C(i) \times R(1) \times R(2) \times E)}{C(e) \times R(2)-R(1) \times H D D \times 24}
$$

Where:

$\mathrm{C}(\mathrm{i})$ is cost of insulation in euro per square meter, $\mathrm{R}(1)$ is initial R-value of section,

$R(2)$ is final R-value of section,

$\mathrm{E}$ is efficiency of the heating system,

$\mathrm{C}(\mathrm{e})$ is cost of energy, expressed in euro per kilowatt-hour,

HDD is heating degree days per year.

\section{Conclusion}

In this paper, basic information on which parts of the house should not be forgotten or left out during the process of insulation of an existing house or during the process of insulation design of the new houses are described. The equation that allows the residents to calculate the payback of the installed insulation is mentioned.

\section{References}

[1] U.S. Department of Energy. Types of insulation, from http:// energy.gov/energysaver/articles/types-insulation.

[2] U.S. Department of Energy. Insulation materials, from http:// energy.gov/energysaver/articles/ where-insulate-home.

[3] U.S. Department of Energy. Insulation materials, from http:// energy.gov/energysaver/articles/ adding-insulation-existing-home.

[4] U.S. Department of Energy. Insulation materials, from http:// energy.gov/energysaver/articles/ estimating-payback-period-additional-insulation. 